\title{
Pertimbangan Hakim dalam Penetapan Dispensasi Perkawinan Dini Akibat Hamil di Luar Nikah pada Pengadilan Agama Bantul
}

\author{
Bagya Agung Prabowo \\ Fakultas Hukum Universitas Islam Indonesia \\ Jl. Tamansiswa No. 158 Yogyakarta 55151 \\ bagya.agung@uii.ac.id
}

\begin{abstract}
This research aims to analyze the following issues: first, $\mathrm{KHI}$ or Compilation of Islamic Laws as a base of consideration for the judge to determine the dispensation towards early marriage - particularly the one due to the illegal pregnancy and second, the law implication towards the establishment of dispensation for the early marriage due to the illegal pregnancy at Religious Court in Bantul. This research is conducted using a field survey method along with the techniques of interview, observation and library research. The method of the research is a judicial-normative one. The result of the research shows that: first, the consideration of a judge in determining the dispensation of an early marriage is classified into two: legal consideration and public equity consideration. The legal consideration here means that when a judge issues his or her legal determination, it must be in accordance with the proposed legal arguments and evidences. Meanwhile, public equity consideration deals with fact that a marriage frequently is considered as an alternative solution for the coming social issues. Another consideration of a judge is that the one who will get married is the biological father of the infant conceived. Second, the dispensation of the early marriage needs to be more tightened in consideration to the increasing underage marriage.
\end{abstract}

Key words : Base of Jury consideration, marriage dispensation, illegal marriage

\begin{abstract}
Abstrak
Penelitian ini bertujuan untuk menganalisis permasalahan: pertama, Kompilasi Hukum Islam (KHI) sebagai dasar pertimbangan hakim dalam penetapan dispensasi perkawinan dini, khususnya dispensasi perkawinan dini akibat hamil di luar nikah. Kedua, implikasi hukum terhadap penetapan dispensasi perkawinan usia dini akibat hamil di luar nikah pada Pengadilan Agama Bantul. Penelitian ini menggunakan metode survei lapangan dengan teknik wawancara, observasi, dan kajian pustaka. Metode penelitian yang digunakan adalah yuridis normatif. Hasil penelitian ini menunjukkan bahwa: pertama, pertimbangan hakim dalam penetapan dispensasi perkawinan dini diklasifikasikan menjadi dua, yaitu pertimbangan hukum dan pertimbangan keadilan masyarakat. Pertimbangan hukum di sini berarti ketika hakim menjatuhkan penetapannya harus sesuai dengan dalil-dalil dan bukti-bukti hukum yang diajukan, sedangkan pertimbangan keadilan masyarakat karena seringkali perkawinan dinilai sebagai solusi alternatif bagi penyelesaian masalah sosial yang akan terjadi. Pertimbangan hakim yang lainnya adalah agar yang akan menikahi adalah ayah biologis anak yang dikandung. Kedua, dispensasi perkawinan dini perlu diperketat karena perceraian akibat perkawinan di bawah umur semakin meningkat.
\end{abstract}

Kata Kunci : Dasar pertimbangan hakim, dispensasi perkawinan, hamil di luar nikah 


\section{Pendahuluan}

Perkawinan mempunyai arti penting dalam kehidupan manusia dimana perkawinan menimbulkan akibat-akibat hukum, bukan hanya kepada suami/isteri yang bersangkutan, melainkan juga kepada anak-anak dan/atau keturunannya, orang tua, keluarga, dan masyarakat pada umumnya. Perkawinan merupakan suatu lembaga suci yang bertujuan untuk membentuk keluarga yang bahagia dan kekal, sesuai dengan Undang-Undang Perkawinan yang menyebutkan bahwa perkawinan ialah ikatan lahir batin antara seorang pria dengan seorang wanita sebagai suamiisteri dengan tujuan membentuk keluarga (rumah-tangga) yang bahagia dan kekal berdasarkan Ketuhanan Yang Maha Esa. ${ }^{1}$

Pertimbangan dari pasal tersebut adalah bahwa sebagai negara yang berdasarkan kepada Pancasila sila pertama, yaitu Ketuhanan Yang Maha Esa, maka perkawinan mempunyai hubungan yang erat sekali dengan agama, sehingga perkawinan bukan saja mempunyai unsur lahir/jasmani, tetapi juga memiliki unsur batin/rohani yang mempunyai peranan penting. Menikah merupakan sunnatullah, sunnah para rasul dan merupakan sunnah yang sangat dianjurkan oleh Rasulullah SAW. Tujuan perkawinan ialah untuk membangun rumah-tangga yang bahagia, harmonis, tenteram, dan sakinah. ${ }^{2}$

Allah memerintahkan kaum muslimin agar menikah, seperti yang tercantum dalam Al-Qur'an surat An-Nur ayat 32:

“Dan nikahkanlah orang-orang yang masih membujang di antara kamu, dan juga orang-orang yang layak (menikah) dari hamba-hamba sahayamu yang laki-laki dan perempuan. Jika mereka miskin, Allah akan memberi kemampuan kepada mereka dengan karunia-Nya. Dan Allah Maha luas (pemberian-Nya), Maha Mengetahui." ${ }^{3}$

Perkawinan adalah suatu lembaga yang diperlukan dan suatu keharusan. Al-Qur'an mengutuk pembujangan sebagai hasil perbuatan setan, dan begitu juga Nabi Muhammad SAW. Menikah berarti memenuhi sunnah Nabi yang dianggap penting. ${ }^{4}$ "Pernikahan adalah sunnah (peraturan)-ku, barang siapa yang benci kepada sunnahku, maka ia bukan termasuk golongan (umat)-ku' (HR. Bukhari Muslim).

Sebagai upaya menjembatani antara kebutuhan kodrati manusia dengan pencapaian esensi dari suatu perkawinan, Undang-Undang Perkawinan Nomor 1

\footnotetext{
${ }^{1}$ Lihat Pasal 1 Undang-Undang Nomor 1 Tahun 1974 tentang Perkawinan.

2 Andi Hakim Nasution, Membina Keluarga Bahagia, Ctk. keempat, PT. Pustaka Antara, Jakarta, 1996, hlm. 28.

${ }^{3}$ Departemen Agama RI, Al-Qur'an dan Terjemabnya, Mekar, Surabaya, 2004, hlm. 494.

${ }^{4}$ Abdul Fadl Mohsin Ebrahim, Aborsi Kontrasepsi dan Mengatasi Kemandulan, Ctk. I, Mizan, Bandung, 1997, hlm. 51.
} 
Tahun 1974 telah menetapkan dasar dan syarat yang harus dipenuhi dalam perkawinan. Salah satu di antaranya adalah ketentuan dalam Pasal 7 ayat (1) yang menyatakan, "Perkawinan hanya diizinkan jika pihak pria sudah mencapai umur 19 (sembilan belas) tahun dan pihak wanita mencapai umur 16 (enam belas) tahun". Sejalan dengan perkembangan kehidupan manusia yang makin kompleks, muncul suatu permasalahan yang terjadi dalam masyarakat, lunturnya moral value atau nilainilai akhlak yaitu pergaulan bebas di kalangan remaja dan hubungan zina menjadi hal biasa sehingga terjadi kehamilan di luar nikah. Akibatnya, orangtua menutupi aib tersebut dengan menikahkan anaknya tanpa mempertimbangkan lagi usia dan masa depan anaknya.

Pengaturan mengenai pemenuhan hak anak diatur dalam Undang-Undang Nomor 23 Tahun 2002 tentang Perlindungan Anak yang meliputi hak tumbuh dan berkembang, hak sipil dan hak kebebasan, hak pengasuhan dan perawatan, hak bermain dan hak berpartisipasi, hak kesehatan, hak pendidikan serta perlindungan khusus. ${ }^{5}$ Hak anak dalam perkawinan usia dini sebenarnya melihat bagaimana perlindungan hak anak jika dijadikan sebagai subjek dalam perkawinan usia dini, dilihat dari sisi hukum nasional sendiri, melihat sisi sejarah peraturan perundangundang tersebut lahir adalah sebagai bukti dari implementasi ratifikasi Konvensi Hak Anak yang bertujuan untuk melindungi kepentingan dan pemenuhan hak di Indonesia.

Idealitanya hakim dalam penetapan dispensasi perkawinan usia dini anak di bawah umur tetap mendasarkan pada pertimbangan yang sesuai dengan UndangUndang Perkawinan Nomor 1 Tahun 1974, yaitu membatasi usia pernikahan minimal 19 tahun untuk laki-laki dan 16 tahun untuk perempuan. Usia dan kedewasaan menjadi hal penting yang harus diperhatikan bagi pria dan wanita yang ingin melangsungkan pernikahan. Realitanya hakim pada Pengadilan Agama Bantul ketika diajukan perkara permohonan dispensasi perkawinan menghadapi masalah yang sangat dilematis. Satu sisi sebagai lembaga yudikatif, harus menegakkan hukum. Tetapi, di sisi lain terbentur dengan fakta, mau tak mau harus memberi dispensasi perkawinan karena untuk menutupi aib keluarga dan demi masa depan anak yang sudah hamil terlebih dulu. ${ }^{6}$

\footnotetext{
${ }^{5}$ Undang-Undang Nomor 23 Tahun 2002 tentang Perlindungan Anak, hlm. 2- 4.

${ }^{6}$ Wawancara dengan Panitera Muda Pengadilan Agama Bantul, Titik Handriyani, 11 November 2010.
} 
Idealitanya implikasi hukum terhadap dispensasi perkawinan usia dini akibat hamil di luar nikah pada Pengadilan Agama Bantul menurut hukum Islam sangat dilarang. Para ulama berselisih faham tentang kebolehan seorang lelaki menikahi perempuan yang telah dizinai. Imam Ahmad, Ibnu Hazim, Ibnu Taimiyah, dan Ibnu Qayyim berpendapat tidak halal perempuan dan laki-laki berzina kawin sebelum bertobat dan harus menunggu masa iddah-nya selesai. ${ }^{7}$ Sedangkan Hanafi dan Syafi'i membolehkan tanpa menunggu masa iddah. ${ }^{8}$ Realitanya akhir-akhir ini di Bantul, angka perkawinan usia dini cukup tinggi, yaitu sekitar 70 kasus pada 2008, 83 kasus pada 2009, dan 90 kasus selama 2010. Hal ini merupakan masalah yang sangat memprihatinkan dan perlu penanganan yang serius antara pemerintah, lembaga terkait, masyarakat serta para orangtua. Wilayah Bantul dipilih sebagai lokasi penelitian karena kasus NTCR (Nikah, Talak, Cerai, dan Rujuk) yang terjadi dan ditangani pada Pengadilan Agama Bantul relatif rendah di Daerah Istimewa Yogyakarta (DIY), namun kasus pernikahan dini lebih tinggi daripada kabupaten dan kota-kota besar lain seperti Jakarta, Makassar dan lainnya. ${ }^{9}$ Angka pernikahan dini di Kabupaten Bantul DIY tergolong tinggi, dan biasanya pihak yang meminta dispensasi perkawinan adalah orangtua. Hal ini terjadi karena si anak sudah hamil terlebih dahulu akibat hubungan bebas yang dilakukannya. Inilah pentingnya penelitian tentang penetapan dispensasi perkawinan dini akibat hamil di luar nikah, supaya tidak muncul asumsi bahwa mereka bebas melakukan hubungan suamiistri di luar nikah karena sangat mudah untuk mendapatkan penetapan dispensasi perkawinan apabila terjadi kehamilan.

\section{Rumusan Masalah}

Berdasarkan latar belakang masalah tersebut, maka dapat dirumuskan permasalahan penelitian sebagai berikut. Pertama, bagaimanakah penggunaan KHI sebagai dasar pertimbangan hakim dalam penetapan dispensasi perkawinan dini akibat hamil di luar nikah pada Pengadilan Agama Bantul? Kedua, bagaimana implikasi hukum terhadap penetapan dispensasi perkawinan usia dini akibat hamil di luar nikah pada Pengadilan Agama Bantul?

\footnotetext{
${ }^{7}$ Departemen Agama RI, Al-Qur'an..., Op.Cit., hlm. 488.

${ }^{8}$ Sayyid Sabiq, Fiqh al-Sunnah Jilid 2, Dar al-Fikr, Beirut, 1992, hlm. 87-88.

${ }^{9}$ Nur Lailah Ahmad, Angka Pernikahan Dini di Bantul Tinggi, dalam http://www.bantulkab.go.id, diakses pada 7 September 2011.
} 


\section{Tujuan Penelitian}

Penelitian ini bertujuan untuk mengetahui: pertama, penggunaan KHI sebagai dasar pertimbangan hakim dalam penetapan dispensasi perkawinan dini akibat hamil di luar nikah pada Pengadilan Agama Bantul. Kedua, implikasi hukum terhadap penetapan dispensasi perkawinan usia dini akibat hamil di luar nikah pada Pengadilan Agama Bantul.

\section{Metode Penelitian}

Jenis penelitian ini adalah penelitian yuridis normatif yang difokuskan pada pertimbangan hakim pengadilan agama dalam penetapan dispensasi perkawinan dini. Dalam konteks ini adalah bagaimanakah dasar pertimbangan hakim dalam penetapan dispensasi perkawinan dini akibat hamil di luar nikah pada Pengadilan Agama Bantul. Terkait dengan jenis penelitian ini, maka ada dua jenis data yang digunakan, yakni data primer yang digali dari lapangan (field research) dengan pihak yang bersinggungan secara langsung atau tidak langsung dengan penelitian ini. Selain itu, digunakan juga data sekunder berupa pustaka (library research) yang terdiri dari dua jenis, yakni perundang-undangan dan Kompilasi Hukum Islam. Teknik analisis data terhadap data primer dilakukan sejak peneliti berada di lapangan. Data yang telah diperoleh dianalisis dengan menggunakan analisis isi/ kandungannya, dalam arti melihat makna yang mendalam dari setiap data yang telah dikumpulkan guna menjawab permasalahan penelitian ini. ${ }^{10}$

\section{Hasil Penelitian dan Pembahasan}

\section{Dasar Pertimbangan Hakim dalam Penetapan Dispensasi Perkawinan Dini Akibat Hamil di Luar Nikah pada Pengadilan Agama Bantul}

Seseorang yang hendak mengajukan perkara permohonan dispensasi kawin, seperti yang tercantum dalam Undang-Undang Perkawinan Pasal 7 ayat (2) yaitu: “Dalam hal penyimpangan terhadap ayat (1) pasal ini dapat meminta dispensasi

${ }^{10}$ P.M. Marzuki, Penelitian Hukum, Prenada Media, Jakarta, 2005, hlm. 67; J. Ibrahim, Teori \& Metodologi Penelitian Hukum Normatif, Bayumedia, Malang, 2006, hlm.272; dan L.J. Moleong, Metodologi Penelitian Kualitatif, PT. Rosdakarya, Bandung, 2001, hlm.189. 
kepada Pengadilan atau Pejabat lain, yang ditunjuk oleh kedua orang tua pihak pria maupun pihak wanita". ${ }^{11}$ Sebelum Ketua Majelis menetapkan penetapan, Ketua Majelis mempunyai pertimbangan-pertimbangan apakah permohonan tersebut dapat dikabulkan atau tidak. Dasar pertimbangan Majelis Hakim adalah sebagai berikut: pertama, pemohon. Majelis Hakim di dalam persidangan akan meneliti apakah orang yang mengajukan perkara permohonan dispensasi tersebut berhak mengajukan atau tidak. Kedua, alasan. Pada persidangan Majelis Hakim menanyakan alasan anak pemohon, kemudian Majelis Hakim meneliti alasan anak pemohon dengan pemohon disurat permohonannya. Apakah alasan anak pemohon dengan pemohon ada persamaan atau tidak. Ketiga, ada larangan perkawinan atau tidak. Bagi calon suami dan calon isteri yang akan melangsungkan pernikahan terdapat halangan atau tidak, sebagaimana yang diatur dalam Undang-Undang Perkawinan. Keempat, kemaslahatan dan kemudharatan. Bila dua insan menjalin cinta, sehingga melakukan hubungan seksual di luar nikah yang menyebabkan kehamilan, maka Pengadilan akan mengabulkan permohonan dispensasi tersebut. Karena dikhawatirkan bila tidak dinikahkan akan menambah dosa dan terjadi perkawinan di bawah tangan yang akan mengacaukan proses-proses hukum yang akan terjadi berikutnya atau mengacaukan hak-hak hukum anak yang dilahirkannya menurut undang-undang. Selain itu, masyarakat akan menghina dan mengucilkan perempuan yang hamil tanpa suami.

Pada praktik sehari-hari hakim ketika diajukan perkara permohonan dispensasi kawin menghadapi masalah yag sangat dilematis. Satu sisi sebagai lembaga yudikatif, harus menegakkan hukum. Tetapi, di sisi lain terbentur dengan fakta: mau tak mau harus menikah. Jika ini yang terjadi maka hakim cenderung berpedoman pada adagium: "mengutamakan kemaslahatan dan menghindari kemudharatan". Konsekuensi dari sikap hakim ini akhirnya cenderung dimanfaatkan sebagian masyarakat, untuk melakukan hubungan biologis yang menyebabkan hamil, dan kemudian mengajukan dispensasi ke pengadilan.

Undang-Undang Nomor 1 Tahun 1974 dan Peraturan Pemerintah Nomor 9 Tahun 1975 tidak mengatur secara jelas apa saja yang dapat dijadikan sebagai alasan agar diberikannya dispensasi usia kawin. Maka dari itu, tiap-tiap keadaan dalam setiap perkara permohonan dispensasi usia kawin akan dipertimbangkan oleh Majelis Hakim dalam pemeriksaan di persidangan. Apabila pengadilan terpaksa

\footnotetext{
${ }^{11}$ Undang-Undang No. 1 Tahun 1974 tentang Perkawinan, Pasal 7 ayat (2).
} 
menolak permohonan tersebut berarti dispensasi usia kawin tidak dapat diberikan. Akibatnya, perkawinan tidak dapat dilaksanakan karena kurangnya persyaratan. Hal-hal yang menentukan apakah dispensasi usia kawin dapat diberikan atau tidak, bukan hanya berdasarkan atas dasar-dasar yuridis, namun juga berdasarkan pertimbangan atau alasan-alasan penting lainnya, seperti misalnya keyakinan hakim.

Permohonan dispensasi usia kawin bagi anak di bawah umur dapat diajukan ke Pengadilan Negeri bagi pemohon yang bukan beragama Islam atau ke Pengadilan Agama bagi pemohon yang beragama Islam. Permohonan dispensasi usia kawin wajib dilampiri dengan surat pengantar dari atau diketahui oleh Kepala Kelurahan/ Kepala Desa setempat dengan ketentuan telah memenuhi syarat. Setelah mendapatkan surat pengantar, pemohon datang ke pengadilan dengan membawa surat permohonan tertulis mengenai hal dispensasi usia kawin yang memuat alasanalasan permohonan dan dilengkapi dengan bukti-bukti dan syarat untuk mengajukan permohonan dispensasi usia kawin.

Pengaturan mengenai dispensasi perkawinan menurut Undang-Undang Nomor 1 Tahun 1974 dapat disimpulkan dari ketentuan Pasal 7 ayat (1) dan ayat (2), yaitu perkawinan hanya diijinkan jika pihak pria sudah mencapai umur 19 tahun dan pihak wanita sudah mencapai umur 16 tahun. Jika adanya penyimpangan, dapat meminta dispensasi kepada pengadilan atau pejabat lain yang ditunjuk oleh kedua orangtua pihak pria maupun pihak wanita. Batas umur yang ditentukan oleh Undang-Undang Nomor 1 Tahun 1974 untuk dapat melangsungkan perkawinan adalah didasarkan pada kematangan jasmani (fisik) dan kematangan rohani, sehingga diharapkan bahwa seorang pria dan wanita pada batas usia tersebut telah mampu memahami konsekuensi dilangsungkannya perkawinan dan mempunyai tanggung jawab untuk dapat membina keluarga bahagia, sesuai yang diharapkan oleh Undang-Undang Nomor 1 Tahun 1974 tentang Perkawinan.

Pada pemeriksaan suatu perkara, hakim bertugas untuk mengkonstatir (mengkonstatasi), mengkualifisir (mengkualifikasi) dan kemudian mengkonstituir (mengkonstitusi). Mengkonstatir artinya hakim harus menilai apakah peristiwa atau fakta-fakta yang dikemukakan oleh para pihak itu adalah benar-benar terjadi. Hal ini hanya dapat dilakukan melalui pembuktian. Membuktikannya artinya mempertimbangkan sacara logis kebenaran suatu fakta atau peristiwa berdasarkan alat-alat bukti yang sah dan menurut hukum pembuktian yang berlaku. 
Dalam pembuktian itu, para pihak memberi dasar-dasar yang cukup kepada hakim yang memeriksa perkara yang bersangkutan guna memberi kepastian tentang kebenaran peristiwa yang diajukan. Fakta ialah keadaan, peristiwa atau perbuatan yang terjadi (dilakukan) dalam dimensi ruang dan waktu. Suatu fakta dapat dikatakan terbukti apabila telah diketahui kapan, di mana, dan bagaimana terjadinya. Misalnya masalah dispensasi kawin, fakta yang perlu dicari kebenarannya adalah apakah seseorang tersebut benar-benar ingin melakukan pernikahan di bawah umur dengan alasan dan bukti-bukti yang dicantumkan dalam berkas permohonan dispensasi yang diajukan orang tuanya ke Pengadilan Agama.

Konkritnya dalam memberi penetapan, hakim tidak boleh keluar dari koridor hukum yang mengatur tentang persoalan yang diperkarakan. Penetapan hakim akan menjadi kepastian hukum dan mempunyai kekuatan mengikat untuk dijalankannya, karena penetapan hakim adalah pernyataan hakim yang dituangkan dalam bentuk tertulis dan diucapkan oleh hakim dalam sidang terbuka untuk umum, sebagai hasil dari pemeriksaan perkara. Ketika ingin menjatuhkan penetapan, hakim memiliki pertimbangan-pertimbangan.

Menurut pendapat penulis pertimbangan hakim diklasifikasikan menjadi dua yaitu: pertama, pertimbangan hukum. Pertimbangan hukum di sini berarti ketika hakim menjatuhkan penetapannya harus sesuai dengan dalil-dalil dan bukti-bukti hukum yang diajukan. Bukti-bukti yang biasa disyaratkan menurut undang-undang adalah: a) bukti surat, meliputi:1) foto copy Surat Kelahiran atas nama anak pemohon yang dikeluarkan oleh Kepala Desa/Kelurahan; 2) surat Pemberitahuan Penolakan Melangsungkan Pernikahan (Model N-9) yang di keluarkan oleh Kantor Urusan Agama; b) bukti saksi. Adapun bukti saksi yang biasa dihadirkan oleh hakim dalam persidangan adalah dua orang. Karena dalam perkara ini adalah perkara permohonan dispensasi kawin, maka keberadaan saksi hanya kalau diperlukan saja.

Pada pertimbangannya, hakim juga berdasarkan hukum Islam. Adapun yang menjadi dasar pertimbangannya adalah:"Menolak bahaya didahulukan atas mendatangkan kebaikan"12, "Kemadharatan harus dihilangkan".

Pada dasarnya setiap insan tidak diizinkan mengadakan suatu kemadharatan, baik berat maupun ringan terhadap dirinya atau terhadap orang lain. Pada prinsipnya kemadharatan harus dihilangkan, tetapi dalam menghilangkan kemadharatan itu tidak boleh sampai menimbulkan kemadharatan lain baik ringan

${ }^{12}$ Wawancara dengan Hakim Pengadilan Agama Bantul, Nur Lailah Ahmad, 11 November 2011. 
apalagi lebih berat. Namun, bila kemadharatan itu tidak dapat dihilangkan kecuali dengan menimbulkan kemadharatan yang lain maka haruslah memilih kemadharatan yang relatif lebih ringan dari yang akan terjadi.

Menurut persepsi hakim, madharatnya adalah ditakutkan bila tidak dinikahkan akan menambah dosa dan terjadi perkawinan di bawah tangan yang akan mengacaukan proses-proses hukum yang akan terjadi berikutnya atau mengacaukan hak-hak hukum anak yang dilahirkannya menurut undang-undang.

Kedua, pertimbangan keadilan masyarakat. Pernikahan seringkali dianggap sebagai solusi alternatif bagi penyelesaian masalah sosial yang akan terjadi yaitu menikahkan anak yang sudah hamil terlebih dahulu untuk menutup malu. Hasil observasi penulis di Pengadilan Agama Bantul, hakim selalu mengabulkan permohonan dispensasi kawin karena hubungan di luar nikah, dengan pertimbangan perempuan yang hamil tanpa suami akan dihina dan dikucilkan oleh masyarakat. Akibatnya, perempuan tersebut tidak mau bergaul dan mementingkan diri sendiri. Hal ini juga bisa terjadi pada anak yang akan dilahirkannya.

\section{Implikasi Hukum terhadap Dispensasi Perkawinan Usia Dini karena Hamil di Luar Nikah di Pengadilan Agama Bantul}

Adapun implikasi hukum menikahi wanita hamil menurut para Imam Mazhab dan menurut Kompilasi Hukum Islam (KHI), yaitu:

Pertama, menurut para Imam Mazhab. Istilah perkawinan wanita hamil adalah perkawinan seorang wanita yang sedang hamil dengan laki-laki sedangkan dia tidak dalam status nikah atau masa iddah karena perkawinan yang sah dengan laki-laki yang mengakibatkan kehamilannya. Ketentuan-ketentuan hukum perkawinan wanita hamil menurut pendapat para imam mazhab (Hanafi, Maliki, Syafi'i dan Ahmad bin Hanbal), mereka berbeda pendapat, pada umumnya dapat dibagi menjadi dua kelompok, yaitu: $\left.{ }^{13} 1\right)$ Imam Hanafi dan Imam Syafi': bahwa wanita hamil akibat zina boleh melangsungkan perkawinan dengan laki-laki yang menghamilinya atau dengan laki-laki lain. Imam Hanafi mengatakan: “Wanita hamil karena zina itu tidak ada iddahnya, bahkan boleh mengawininya, tetapi tidak boleh melakukan hubungan seks hingga dia melahirkan kandungannya". Menurut Imam Syafi'i: “Hubungan seks karena zina itu tidak ada iddahnya, wanita yang hamil karena

${ }^{13}$ Muhammad Jawad Mughniyah, Fiqh Lima Maz̧hab, Basrie Press, Jakarta, tanpa tahun, hlm. 43-45 
zina itu boleh dikawini, dan boleh melakukan hubungan seks sekalipun dalam keadaan hamil."

Menurut Imam Hanafi meskipun perkawinan wanita hamil dapat dilangsungkan dengan laki-laki, tetapi dia tidak boleh disetubuhi, sehingga bayi yang dalam kandungan itu lahir. Menurut Imam Syafi'i, perkawinan wanita hamil itu dapat dilangsungkan, dapat pula dilakukan persetubuhan dengannya. Memperhatikan pendapat Imam Syafi'i, maka seorang wanita hamil karena hasil melakukan hubungan seks di luar nikah jika dia melangsungkan perkawinan dengan seorang laki-laki, maka kehamilannya itu tidak mempengaruhi dalam perkawinannya; 2) Imam Malik dan Imam Ahmad bin Hambal. Menurut Imam Malik dan Ahmad bin Hanbal sama halnya dengan yang dikawini dalam bentuk zina atau syubhat atau kawin fasid, maka dia harus mensucikan diri dalam waktu yang sama dengan iddah. Untuk mendukung pendapatnya, mereka mengemukakan alasan dengan sabda Nabi Muhammad SAW. “Tidak halal bagi seorang yang beriman kepada Allah dan hari Akhirat menyiramkan airnya (sperma) kepada tanaman orang lain, yakni wanita-wanita tawanan yang hamil, tidak halal bagi seorang yang beriman kepada Allah dan hari akhirat mengumpuli wanita tawanan perang sampai menghabiskan istibra'nya (iddah) satu kali haid" (Hr. Imam Bukhari).

Imam Malik dan Imam Ahmad bin Hambal mengambil kesimpulan dari kedua hadits tersebut, bahwa wanita hamil tidak boleh dikawini, karena dia perlu masa iddah. Mereka memberlakukan secara umum, termasuk wanita hamil dari perkawinan yang sah, juga wanita hamil dari akibat perbuatan zina. Adapun penentuan larangan perkawinan wanita hamil tersebut berawal dari pendapat mereka yaitu, wanita hamil karena zina tetap memiliki masa iddah, maka wanita hamil tidak boleh melangsungkan perkawinan sampai dia melahirkan kandungannya. ${ }^{14}$

Wanita hamil dilarang melangsungkan perkawinan. Bahkan, menurut Imam Ahmad bin Hambal, wanita hamil karena zina harus bertaubat, baru dapat melangsungkan perkawinan dengan laki-laki yang mengawininya. Menurut hadits tersebut, mereka berkesimpulan bahwa wanita hamil dilarang melangsungkan perkawinan, karena dia perlu beriddah sampai melahirkan kandungannya. Pendapat mereka ini dapat dimengerti agar menghindari adanya pencampuran keturunan,

${ }^{14}$ Ibid., hlm. 46. 
yaitu keturunan yang punya bibit dan keturunan yang mengawini ibunya. Maka Imam Malik dan Ahmad bin Hanbal memberlakukan iddah secara umum terhadap wanita hamil, apakah hamilnya itu karena perkawinan yang sah, ataukah kehamilannya itu akibat dari hubungan seksual diluar nikah. Maka dengan demikian, perkawinan wanita hamil dilarang. ${ }^{15}$

Berdasarkan kedua mazhab di atas menurut penulis mazhab Imam Hanafi dan Imam Syafi'i lebih mudah untuk diterapkan dan memberi jalan keluar bagi mereka yang telah terlanjur hamil sebelum menikah. Tetapi penulis lebih setuju dengan pendapat Imam Hanafi: “Wanita hamil karena zina itu tidak ada iddahnya, bahkan boleh mengawininya, tetapi tidak boleh melakukan hubungan seks hingga dia melahirkan kandungannya". Menurut Imam Hanafi meskipun perkawinan wanita hamil dapat dilangsungkan dengan laki-laki, tetapi dia tidak boleh disetubuhi, sehingga bayi yang dalam kandungan itu lahir. ${ }^{16}$

Kedua, menurut Kompilasi Hukum Islam (KHI). Status perkawinan wanita hamil dalam KHI di Indonesia disebutkan pada Bab VIII Pasal 53 ayat (1, 2 dan 3), yaitu: 1) seorang wanita hamil di luar nikah dapat dikawinkan dengan pria menghamilinya; 2) perkawinan dengan wanita hamil yang disebutkan pada ayat (1) dapat dilangsungkan tanpa menunggu lebih dahulu kelahiran anaknya; 3) dengan dilangsungkannya perkawinan pada saat wanita hamil tidak diperlukan perkawinan ulang setelah anak yang dikandung lahir.

Pasal 53 ayat (2) KHI menyatakan bahwa perkawinan wanita hamil itu benarbenar dilangsungkan ketika wanita itu dalam keadaan hamil. Kelahiran bayi yang dalam kandungannya tidak perlu ditunggu. Menurut KHI, perkawinan wanita hamil akibat perbuatan zina tidak mengenal iddah. Namun, perkawinan wanita hamil seperti Pasal 53 ayat (1), hanya boleh dikawinkan dengan laki-laki yang menghamilinya.

Mengetahui siapakah laki-laki yang menghamili wanita itu sangat sulit, apalagi dihubungkan dengan pembuktian menurut hukum Islam harus disaksikan oleh empat orang saksi. Pembuktian itu semakin sulit apabila adanya usaha secara sengaja menutup-nutupi, atau orang yang pernah menzinahi beberapa orang. Pasal 53 ayat (1 dan 2) tersebut semacam ada sikap yang tidak konsisten. Karena apabila berpedoman kepada Pasal 53 ayat (2) KHI, tersebut ternyata hanya berpedoman

\footnotetext{
${ }^{15}$ Ibid., hlm. 47.

${ }^{16}$ Aliy As 'ad, Fathul Mu'in Jilid 2, terjemahan Moh. Tolchah Mansor, Menara, Kudus, tanpa tahun, hlm. 21.
} 
kepada formalitasnya saja, yaitu karena wanita hamil tersebut belum pernah menikah, maka kemudian ketentuan yang berlaku baginya adalah hak kegadisan, walaupun kenyataanya wanita itu telah hamil.

Pasal 53 ayat (3) menyatakan, bahwa dengan dilangsungkannya perkawinan pada saat wanita hamil, tidak diperlukan lagi perkawinan ulang setelah anak yang dikandung lahir. Adanya ketentuan bahwa perkawinan tersebut tidak perlu diulangi lagi, maka menjadi isyarat bahwa perkawinan terdahulu telah dinyatakan sah.

\section{Implikasi Hukum Menyangkut Hak dan Kewajiban antara Anak, Ibu yang Melahirkannya dan Ayah Biologis (genetiknya)}

Beberapa akibat hukum menyangkut hak dan kewajiban antara anak, ibu yang melahirkannya dan ayah biologis (genetiknya), yaitu: ${ }^{17}$ a) hubungan nasab. Pasal 100 Kompilasi Hukum Islam sebagaimana yang telah dikemukakan, dinyatakan bahwa anak yang lahir di luar perkawinan hanya mempunyai hubungan nasab dengan ibunya dan keluarga ibunya saja. Hal demikian secara hukum anak tersebut sama sekali tidak dapat dinisbahkan kepada ayah biologis, meskipun secara nyata ayah biologis (genetik) tersebut merupakan laki-laki yang menghamili wanita yang melahirkannya itu; b) nafkah. Karena status anak tersebut menurut hukum hanya mempunyai hubungan nasab dengan ibunya dan keluarga ibunya semata, maka yang wajib memberikan nafkah anak tersebut adalah ibunya dan keluarga ibunya saja. Sedangkan bagi ayah biologis (genetik), meskipun anak tersebut secara biologis merupakan anak yang berasal dari spermanya, namun secara yuridis formal sebagaimana maksud Pasal 100 Kompilasi Hukum Islam di atas, tidak mempunyai kewajiban hukum memberikan nafkah kepada anak tersebut; c) hak-hak waris. Sebagai akibat lanjut dari hubungan nasab seperti yang dikemukakan, maka anak tersebut hanya mempunyai hubungan waris-mewarisi dengan ibunya dan keluarga ibunya saja, sebagaimana yang ditegaskan pada Pasal 186 Kompilasi Hukum Islam: "Anak yang lahir di luar perkawinan hanya mempunyai hubungan saling mewarisi dengan ibunya dan keluarga dari pihak ibunya". Maka anak tersebut secara hukum tidak mempunyai hubungan hukum saling mewarisi dengan ayah biologis (genetiknya); d) hak perwalian. Apabila dalam suatu kasus bahwa anak yang lahir akibat dari perbuatan zina (di luar perkawinan) tersebut ternyata wanita, dan setelah dewasa anak tersebut akan menikah, maka ayah biologis (genetik) tersebut tidak

\footnotetext{
${ }^{17}$ Sudarsono, Hukum Perkawinan Nasional, Ctk. III, Rineka Cipta, Jakarta, 2005, hlm. 98.
} 
berhak atau tidak sah untuk menikahkannya (menjadi wali nikah), sebagaimana ketentuan wali nikah yang ditentukan dalam Kompilasi Hukum Islam.

Adapun status anak dari perkawinan wanita hamil akibat zina oleh para Imam Mazhab berbeda pendapat. Para ulama sepakat bahwa anak zina itu tidak dinasabkan kepada ayahnya, akan tetapi dinasabkan kepada ibunya. Sebagaimana yang dijelaskan oleh Ibnu Rusyd dalam Bidayatul Mujtahid:18 "Ulama telah sepakat bahwa anak zina itu tidak dinasabkan kepada ayahnya, kecuali yang terjadi di zaman jahiliyah". Mereka beralasan karena Sabda Nabi Muhammad SAW yang mengatakan: "Anak itu bagi yang melahirkan...".

Kemudian Imam Syafi'i berpendapat, paling cepat umur kehamilannya itu adalah enam bulan, apabila perkawinan telah lebih dari enam bulan, lalu anak tersebut belum lahir, maka anak tersebut mempunyai hubungan nasab kepada suaminya. Sebaliknya apabila kurang dari enam bulan, maka nasab anak tersebut dihubungkan kepada ibunya. ${ }^{19}$

Ibnu Rusyd mengatakan bahwa Imam Syafi'i berkata:

"Siapapun yang kawin dengan seorang wanita dan belum mencampurinya sesudah aqad nikah, lalu wanita itu, melahirkan setelah enam bulan dari waktu aqad nikah bukan terjadinya percampuran itu, maka anak tersebut tidak dipertalikan nasabnya kepada seorang laki -laki yang mengawini, kecuali jika ibu itu melahirkannya setelah lebih dari enam bulan." 20

Pendapat tersebut, jika diperhatikan dengan pengertian dari perkawinan (nikah) itu sendiri secara istilah, adalah akad penghalalan persetubuhan. Maka konsekuensinya jika seseorang wanita ternyata hamil sebelum akad dimaksud, maka kehamilan wanita tersebut tidak dihargai, bibit itu dapat milik laki-laki mana saja, karena apabila anak itu lahir, dia tidak memiliki nasab kepada laki-laki, tetapi hanya memiliki nasab kepada ibunya. Selain alasan tersebut, jumhur ulama mengartikan lafazh al-firasy adalah wanita. Imam Hanafi beralasan dengan memahami lafazh alfirasy yang berarti laki-laki (Suami), maka hubungan nasab anak tersebut adalah dengan suami ibunya. Selain alasan tersebut, Imam Hanafi memahami pengertian lafazh nikah menurut hakiki adalah setubuh. ${ }^{21}$ Memperhatikan pendapat Imam Hanafi tersebut, maka setiap anak yang lahir akan dihubungkan nasabnya kepada

\footnotetext{
${ }^{18}$ Ibnu Rusyd, Bidayatul Mujtabid, ]uz. III, Mushtafaal -Halaby wa Auladihi, Mesir, 1960, hlm. 358.

${ }^{19}$ Abdurrahman Ghazali, Fiqib Munakahat, Prenada Media, Jakarta, 2003, hlm. 65.

${ }^{20}$ Ibnu Rusyd, Bidayatul Mujtahid, Op.Cit., hlm. 364.

${ }^{21}$ Abdurrahman Ghazali, Fiqih Munakahat..., Op.Cit., hlm. 94.
} 
laki-laki yang memiliki bibit. Ketentuan ini terlihat dengan sikapnya dalam mengartikan nikah dengan setubuh. Maka konsekuensinya apabila terjadi hubungan seksual yang mengakibatkan lahirnya seorang bayi, maka bayi tersebut adalah anak dari laki -laki yang melakukan perbuatan zina tersebut. Maka bayi yang lahir dari perkawinan wanita hamil itu bukan secara langsung dinasabkan kepada laki-laki yang mengawini ibunya bayi, tetapi dinasabkan kepada mereka yang mempunyai bibit.

Menyoroti pendapat para Imam Mazhab tentang keabsahan perkawinan wanita hamil dan menghubungkannya dengan Kompilasi Hukum Islam di Indonesia menurut penulis tampak keduanya masih bisa dikatakan sejalan. Inti pendapat tersebut adalah kebolehan perkawinan wanita hamil. Adapun status nasab anak yang lahir dalam perkawinan wanita hamil dalam KHI dinasabkan kepada suami ibunya hal ini sejalan dengan pendapat Imam Hanafi yang mengaitkan nasab anak kepada pemilik bibit secara umum. Perbedaannya adalah apabila ternyata pemilik bibit itu bukan orang yang mengawini wanita hamil itu. Imam Hanafi menghubungkannya bukan kepada laki-laki yang mengawininya, tetapi kepada pemilik bibit yang menyebabkan lahirnya anak tersebut. Menurut KHI tetap menghubungkan nasab anak kepada laki-laki yang mengawini wanita hamil tersebut. ${ }^{22}$ Penulis melihat bahwa pembuat Kompilasi Hukum Islam di Indonesia mencerminkan sikap kehatihatian, terikat sepenuhnya dengan hukum Islam, tetapi tidak mengacu kepada figh mazhab tertentu. Jika melihat kepada pendapat Imam Mazhab dan KHI yang berlaku di Indonesia, maka dalam hal status perkawinan wanita hamil dengan laki-laki, KHI lebih bersifat kehati-hatian, yang hanya membolehkan kawin dengan laki-laki yang menghamilinya. Bagaimana kalau perkawinannya itu dilangsungkan dalam keadaan hamil tua, maka pendapat Imam Syafi'i lebih menyelamatkan kepada status anak. Karena menurut Imam Syafi'i bahwa pengakuan status anak itu ditentukan dengan masa kehamilan dalam perkawinannya dengan seorang laki-laki, yaitu apabila perkawinannya itu adalah enam bulan, lalu anak lahir, maka anak tersebut memiliki hubungan nasab kepada ayahnya. Seandainya kurang dari enam bulan, maka nasab anak tersebut dihubungkan kepada ibunya. ${ }^{23}$ Sedangkan dalam KHI tidak ada menyebutkan usia kehamilannya, ini berarti bahwa apabila seorang wanita

\footnotetext{
${ }^{22}$ Departemen Agama RI, Kompilasi Hukum Islam di Indonesia, Direktorat Jenderal Pembinaan Kelembagaan Agama Islam, Jakarta, 2000, hlm. 83.

${ }^{23}$ Faturrahman Azhari, Pandangan Ulama terhadap Iddah Perempuan Hamil di luar Nikah, Pustaka Mizan, Bandung, 2007, hlm. 114.
} 
hamil kemudian kawin dengan laki-laki maka anak yang dalam kandungannya adalah anak laki-laki yang mengawininya. Ini berarti KHI sejalan dengan pendapat Imam Hanafi yang melanjutkan nasab anak kepada pemilik bibitnya. Hanya saja Imam Hanafi membolehkan kawin dengan laki-laki yang bukan menghamilinya.

Para ulama menggunakan dalil Al-Qur'an dalam menentukan hukum status perkawinan wanita hamil, terutama bagi Imam Hanafi dan Imam Syafi'i, yaitu memahami Al-Qur'an pada surah An-Nur ayat 2. Sedangkan Imam Malik dan Imam Ahmad bin Hanbal tidak memahami ayat tersebut, tetapi memberlakukan dalil lain. Karenanya terjadilah perbedaan dalam menentukan hukum status perkawinan wanita hamil menurut Imam Ahmad bin Hanbal di samping dalil Al-Qur'an, para ulama menggunakan hadits Nabi Muhammad SAW, baik dalam menentukan status perkawinan, status nasab anak maupun akibat hukum yang timbul. Baik Imam Hanafi dan Syafi'i yang membolehkan perkawinan wanita hamil, maupun Imam Malik dan Imam Ahmad bin Hanbal yang melarang perkawinan wanita hamil, mereka menggunakan dalil atau alasan dari hadits-hadits Nabi Muhammad SAW. Tetapi, hadits-hadits yang dipergunakan berbeda bunyinya, sehingga berbeda pula kesimpulan hukumnya di samping kedua dalil tersebut (Al-Qur'an dan hadits) para ulama mempergunakan ijtihad. Penggunaan ijtihad tampak terlihat ketika menentukan status nasab anak. Jumhur ulama berijtihad dengan memahami lafaz "nikah" dalam arti secara istilahi sedangkan Imam Hanafi memahami dalam arti hakiki. Dalil-dalil yang dipergunakan oleh para ulama dalam mendukung pendapatnya itu sesuai dengan dasar-dasar istinbath hukum Islam yang ditetapkan oleh konsensus ulama. Memperhatikan dalil-dalil atau alasan yang dipergunakan oleh para ulama dan KHI, maka pendapat ulama dan KHI yang membenarkan perkawinan wanita hamil, walaupun dengan laki-laki yang menghamilinya, maka jangan sampai kawin hamil menjadi semakin terbiasa, tetapi semestinya ada rasa tabu dan penyesalan bagi pelakunya. Sebenarnya pendapat para ulama dan KHI hanya memberikan jalan keluar bagi mereka yang telah terlanjur hamil sebelum menikah. Ini bukan berarti memberikan peluang untuk hamil sebelum menikah (berbuat zina), sebab perbuatan zina suatu perbuatan yang sangat jahat dan dosa besar. 


\section{Penutup}

Berdasarkan hasil analisis data penelitian ini, maka dapat disimpulkan, pertama, dasar pertimbangan hakim dalam penetapan dispensasi perkawinan dini akibat hamil di luar nikah pada Pengadilan Agama Bantul yaitu hakim memeriksa secara seksama dan tidak mudah memberi izin kecuali benar-benar keadaan sudah terpaksa untuk perkara-perkara yang mendesak, di mana lebih banyak kemudharatannya daripada kemaslahatan. Menurut pendapat penulis pertimbangan hakim diklasifikasikan menjadi dua, yaitu pertimbangan hukum dan pertimbangan keadilan masyarakat. Pertimbangan hukum di sini berarti ketika hakim menjatuhkan penetapannya harus sesuai dengan dalil-dalil dan bukti-bukti hukum yang diajukan, sedangkan Pertimbangan Keadilan Masyarakat karena seringkali perkawinan dinilai sebagai solusi alternatif bagi penyelesaian masalah sosial yang akan terjadi. Pertimbangan hakim yang lainnya adalah agar yang akan menikahi adalah ayah biologis anak yang dikandung.

Kedua, implikasi hukum terhadap dispensasi perkawinan usia dini karena hamil di luar nikah pada Pengadilan Agama Bantul adalah menurut para Imam Mazhab dibagi menjadi dua kelompok, yaitu: Imam Hanafi dan Imam Syafi'i, bahwa wanita hamil akibat zina boleh melangsungkan perkawinan dengan laki-laki yang menghamilinya atau dengan laki-laki lain. Menurut Imam Malik dan Ahmad bin Hanbal sama halnya dengan yang dikawini dalam bentuk zina atau syubhat atau kawin fasid, maka dia harus mensucikan diri dalam waktu yang sama dengan iddah. Penulis lebih setuju dengan pendapat Imam Hanafi: “Wanita hamil karena zina itu tidak ada iddahnya, bahkan boleh mengawininya, tetapi tidak boleh melakukan hubungan seks hingga dia melahirkan kandungannya". Menurut Imam Hanafi meskipun perkawinan wanita hamil dapat dilangsungkan dengan laki-laki yang menghamili, tetapi dia tidak boleh disetubuhi, sehingga bayi yang dalam kandungan itu lahir. Pendapat Imam Hanafi ini sesuai dengan KHI Pasal 53 ayat (2) menyatakan bahwa perkawinan wanita hamil itu benar-benar dilangsungkan ketika wanita itu dalam keadaan hamil. Kelahiran bayi yang dalam kandungannya tidak perlu ditunggu. Menurut KHI perkawinan wanita hamil akibat perbuatan zina tidak mengenal iddah. Namun perkawinan wanita hamil seperti Pasal 53 ayat (1), hanya boleh dikawinkan dengan laki-laki yang menghamilinya. Konkritnya dalam memberi penetapan, hakim tidak boleh keluar dari koridor hukum yang mengatur tentang 
persoalan yang diperkarakan. Penetapan hakim akan menjadi kepastian hukum dan mempunyai kekuatan mengikat untuk dijalankannya. Hakim harus lebih cermat sebelum memberi dispensasi perkawinan dini karena hamil diluar nikah. Dispensasi perkawinan dini perlu diperketat karena perceraian akibat perkawinan di bawah umur semakin meningkat. Masalah pernikahan di bawah umur harus diatur lebih detil. Sehingga bisa menjadi pedoman bagi hakim dalam mempertimbangkan perkara ini, dan dapat menjadi pendidikan hukum bagi masyarakat. Perbuatan zina agar tidak dianggap perbuatan remeh dan menjadi biasa karena adanya dispensasi perkawinan usia dini.

\section{Daftar Pustaka}

Aswar, Cut, Hukum Menikahi Wanita Hamil karena Zina, dalam Chuzaimah T. Yanggo dan Hafiz Anshary A.Z (ed), Problematika Hukum Islam Kontemporer II,cet.II, Pustaka Firdaus, Jakarta, 1996.

As 'ad, Aliy, Fathul Mu'in Jilid 2, terj. Moh. Tolchah Mansor, Menara, Kudus, tanpa tahun.

Athibi, Ukasyah, Wanita Mengapa Merosot Akhlaknya, Gema Insani, Jakarta, 1998.

Azhar Basyir, Ahmad, Hukum Perkawinan Islam, Ctk kesembilan, UII Press, Yogyakarta, 1999.

Azhari, Faturrahman, Pandangan Ulama terhadap Iddah Perempuan Hamil di luar Nikah, Pustaka Mizan, Bandung, 2007.

Az-Zuhaili, Wahbah, Al-Fiqh Al-Islam wa Adillatuh, Ctk. IV, Dar al-Fikr, Damaskus, 1997.

Al-Figh Al-Islam wa Adillatuh, Ctk IX, Dar al-Fikr, Damaskus, 1997.

Bushar, Muhammad, Pokok-Pokok Hukum Adat, cet.II, Pradnya Paramita, Jakarta, 2000.

Departemen Agama RI, Al-Qur'an dan Terjemahnya, Mekar, Surabaya, 2004.

Departemen Agama RI, Kompilasi Hukum Islam di Indonesia, Direktorat Jenderal Pembinaan Kelembagaan Agama Islam, Jakarta, 2000.

Direktorat Jendral Pembinaan Kelembagaan Agama Islam, Ilmu Fiqh, Ctk. 2, Jilid 2, Departemen Agama, Jakarta, 1984.

, Bahan Penyuluhan Hukum, Departemen Agama RI, Jakarta, 2001.

Fadl Mohsin Ebrahim, Abdul, Aborsi Kontrasepsi dan Mengatasi Kemandulan, Ctk. I, Mizan, Bandung, 1997.

Ghazali, Abdurrahman, Fiqih Munakahat, Prenada Media, Jakarta, 2003. 
Hakim Nasution, Andi, Membina Keluarga Bahagia, Ctk. Keempat, PT. Pustaka Antara, Jakarta, 1996.

Ibrahim, J., Teori E Metodologi Penelitian Hukum Normatif, Bayumedia, Malang, 2006.

Ichtiar Baru Van Hove, Ensiklopedi Islam 4, ctk. 3, Jakarta, 1994.

Ensiklopedi Hukum Islam, Jakarta, 1960.

Jawad Mughniyah, Muhammad, Figh Lima Mazhab, Basrie Press, Jakarta, tanpa tahun. al-Ahwal asy-Syakhsiyyah, cet. I, Daral-'Ilmi li al-Malayin, Bairut, 1964.

Mujieb, M. Abdul, et.al., Kamus Istilah Fiqih, Pustaka Firdaus, Jakarta, 1994.

Marzuki, P.M., Penelitian Hukum, Prenada Media, Jakarta, 2005

Moleong, J.L., Metodologi Penelitian Kualitatif, PT. Rosdakarya, Bandung, 2001.

Nurdin, Subhan, Kado Pernikahan Buat Generasiku, Ctk. 3, Mujahid Press, Bandung, 2002.

Rusyd, Ibnu, Bidayatul Mujtahid, Juz III, Mushtafa al-Halaby wa Auladihi, Mesir, 1960.

R. Subekti dan R. Tjitrosoedibio, Kamus Hukum, PT. Pradnya Paramitha, Jakarta, 1996.

Sabiq, Sayyid, Figh al-Sunnah Jilid 2, Dar al-Fikr, Beirut, 1992.

Salim Bin Smeer Al Hadhrami, Safinatun Najah, terj. Abdul Kadir Aljufri, Mutiara Ilmu, Surabaya, 1994.

Sastroatmodjo, Arso dan Wasit Aulawi, Hukum Pernikahan di Indonesia, ctk 1, Bulan Bintang, Jakarta, 1975.

Sudarsono, Hukum Perkawinan Nasional, Ctk. III, Rineka Cipta, Jakarta, 2005.

Supramono, Gatot, Segi-Segi Hukum Hubungan Luar Nikah, Djambatan, Jakarta, 1998.

Thayib, Anshari, Struktur Rumah Tangga Muslim, ctk 3, PT. Risalah Gusti, Surabaya, 1994.

Usadaningsih, Widiati, Dispensasi Perkawinan di bawah Umur menurut Undang-Undang Nomor 1 tahun 1994 tentang Perkawinan (Studi Kasus terhadap Penetapan No. 001/Pdt. P/1996/PAJS), dalam Tesis Magister Fakultas Hukum Universitas Indonesia, Jakarta, 2007.

Van Apeldoorn, L. J., alih bahasa oleh C. S.T. Kansil, Pengantar Ilmu Hukum dan Tata Hukum Indonesia, Balai Pustaka, Jakarta, 1986.

Varia Peradilan, No. 291 Tahun XXV Februari 2010.

Undang-Undang Nomor 1 Tahun 1974 tentang Perkawinan.

Undang-Undang Nomor 23 Tahun 2002 tentang Perlindungan Anak.

Inpres Nomor 1 Tahun 1991, Kompilasi Hukum Islam.

Lailah Ahmad, Nur, Angka Pernikahan Dini di Bantul Tinggi, dalam: http:// www.bantulkab.go.id, di akses pada tanggal 7 September 2010. 